\title{
ЭКСПЕРТИЗА ВЫСКАЗЫВАНИЯ Д.И. МЕНДЕЛЕЕВА О БРИТАНСКОМ ЛИМИТЕ ДЛЯ БЕЗОПАСНОГО КЕРОСИНА
}

\author{
С. Г. Алексеев, В. В. Смирнов, Н. М. Барбин
}

СЕРГЕЙ ГЕННАДЬЕВИЧ АЛЕКСЕЕВ - кандидат химических наук, доцент, научный консультант автономной некоммерческой организации «Уральский научно-исследовательский институт Bсероссийского добровольного пожарного общества».E-mail: 3608113@mail.ru.

ВИТАЛИЙ ВЛАДИМИРОВИЧ СМИРНОВ - старший преподаватель кафедры пожарной безопасности в строительстве Уральского института государственной противопожарной службы МЧС России.

НИКОЛАЙ МИХАЙЛОВИЧ БАРБИН - доктор технических наук, доиент, ведущчй научный сотрудник научно-исследовательского отдела Уральского института государственной противопожарной службы МЧС России.

620137, Свердловскаяобласть, г. Екатеринбург, ул. Учителей, 32. АНО«Уральскийнаучно-исследовательский институт ВДПО».

620062, Свердловская область, г. Екатеринбург, ул. Мира, д. 22. Уральский институт ГПС МЧС России.

В работе проведена экспертиза высказывания Д.И. Менделеева о «надломе привычек» Британского парламента при установлении нового лимита для безопасного керосина в 1879 году. Формально оснований для этого высказывания Д.И. Менделеева нет, поскольку официальное уменьшение этого лимита было связано с переходом от стандартного английского прибора открытого типа к новому закрытому тестеру Абеля. Поскольку в научно-практической деятельности Д.И. Менделеева отсутствует, такая черта, как небрежность, поэтому возникает закономерный вопрос: кто прав? Для решения этой задачи реконструирована картина основных событий, связанных с появлением безопасных лимитов по температуре вспышке (воспламенения) для осветительных масел (керосинов) На основании анализа полученной картины событий выявлено, что при переходе на новый лимит $73^{\circ} \mathrm{F}$ присутствовала заинтересованность со стороны Нефтяной комиссии, которая была ответственная за допуск импортных керосинов на внутренний рынок Британских островов. При сравнительном изучении методик определения температуры вспышки в стандартном английском приборе, аппарате Джона Тальябу и закрытом тестере Абеля установлено, что необходимости в прямой фальсификации результатов контрольных испытаний керосина не было. Несовершенство методики Нефтяного закона 1868 года, а также организация проведения этих испытаний позволяла без особых усилий достигнуть желаемого результата для Нефтяной комиссии при Британском парламенте. Таким образом утверждение Д.И. Менделеева о «надломе привычек» Британского парламента следует признать справедливым не в полной мере.

Ключевые слова: Менделеев, Британский Парламент, температура вспышки, керосин, Нефтяной закон, нафтометр, пожар, взрыв. 


\title{
EXAMINATION OF THE D.I. MENDELEEV'S EXPRESSION ABOUT THE BRITISH LIMIT FOR SAFE KEROSENE
}

\author{
S. G. Alexeev, V.V. Smirnov, N. M. Barbin \\ 32, Uchitelej st., Ekaterinburg, Sverdlovskaya Oblast, 620137, Russia. ANO "Ural research Institute of the AVFS". \\ 22, Mira st., Ekaterinburg, Sverdlovskaya Oblast, 620062, Russia. Ural Institute of the SFS MES of Russia.
}

\begin{abstract}
An examination of the D.I. Mendeleev's statement on the "break of habits" of the British Parliament in setting a new limit for safe kerosene in 1879 are conducted. Formally, there are not for the ground for this complaint of D.I. Mendeleev, because the official decrease in this limit are associated with the transition from a standard English open type device to the new closed Abel tester. Since in the scientific and practical activities D.I. Mendeleev is absent, such a trait as negligence, so a logical question arises: who is right? To solve this problem, the picture of the main events related to the appearance of safe limits on the flash (ignition, fire) point for lighting oils (kerosene) are reconstructed. Based on the analysis of the resulting picture of events, it are revealed that upon the transition to the new $73^{\circ} \mathrm{F}$ limit, there was interest from the Petroleum Association, which was responsible for allowing imported kerosene to enter the British Isles domestic market. A comparative study of the methods for determining the flash temperature in the English Standard Tester, John Tagliabue apparatus and the Abel closed device is shown that there is not direct falsification of the results of control tests of mineral oils. The imperfection of the technique of the Petroleum Act of 1868, as well as the organization of these tests, made it possible to achieve the desired result for the Petroleum Association under the British Parliament without much effort. Thus, statement D.I. Mendeleev about "breaking the habits" of the British Parliament should not be recognized fair to the fullest.
\end{abstract}

Keywords: Mendeleev, British Parliament, flash point, kerosene, Petroleum law, naphthometer, fire, explosion.

Специалисты нефтегазовой отрасли высоко ценят заслуги Дмитрия Ивановича Менделеева в области развития нефтяного дела в России. Основные его работы по данной тематике приведены в отдельном 10-м томе собраний сочинений [1]. Предметом настоящего исследования явилось следующее высказывание Д.И. Менделеева: «... Англия парламентским актом 1871 2. (The Petroleum Act, 1871, пункт 3) назначила температуру вспышки $100^{\circ} \Phi$., т.е. $37,8^{\circ}$ Ц., но должна была скоро отступить, потому что, как ни желательно обезопасить жителей законом противу случайностей пожара от повсеместного потребления очень опасного материала, да нельзя было. Спрос был большой, а предложения было мало, цены на такой товар должны быть у американщев высоки. Их керосины дают вспьику чаме ниже $20^{\circ}$, много $25^{\circ}$, m. е. очень опасныл. Но нельзя было заставить законом переделать природу американской нефти и неладно оказалось парламентским актом заставлять дорого платить за ходячий, общераспространенный товар. И пришлось парламенту, хоть он и не любит переделывать свои постановления, здесь надломить свои привычки. Издан был Petroleum Act, 1879, пункт 26 по которому была допущена норма дозволенного к ввозу керосина до $70^{\circ}$ Ф., ${ }^{1}$ или 22.8 Ц.» [1], которое было опубликовано в 1885 году в журнале «Вестник промышленности».

Британская точка зрения по этому поводу, говорит, что данному событию предшествовала целая череда событий. Так, в 1862 году Британский парламент закрепляет в Нефтяном законе (Petroleum Act) понятие «петролеум» (petroleum), ${ }^{2}$ под которое попадала любая жидкость, способная давать горючие пары при температуре менее $100{ }^{\circ} \mathrm{F}$, а также порядок транспортировки и обращения петролеума на территории Англии, Уэль$\mathrm{ca}$, Шотландии и частично Ирландии ${ }^{3}$ [2]. Однако в Нефтяном законе 1862 года не был заложен метод определения температуры петролеума, при которой он способен давать горючие пары. Этот не-

\footnotetext{
${ }^{1}$ Очевидно в 10-м томе собрания сочинений Д.И. Менделеева [1] допущена опечатка. В 1879 году официальный лимит для «безопасного» керосина был установлен $73^{\circ} \mathrm{F}$ [2], что действительно соответствует $22,8^{\circ} \mathrm{C}$. ${ }^{2}$ В современном понимании данный термин эквивалентен де-
финиции «легковоспламеняющаяся жидкость» или «ЛВЖ».

${ }^{3}$ На других территориях Британской империи в последующем принимались свои локальные нефтяные (керосиновые) законы.
} 
достаток был исправлен в 1868 году, когда в приложении к Нефтяному закону 1868 года появилось описание прибора и методика определения температуры вспышки. В следующей редакции Нефтяного закона от 1871 года лимит для безопасного керосина, стандартный английский прибор и открытый метод определения температуры вспышки образца 1868 года сохранились без изменений. Далее в 1879 году было легализовано предложение химика королевского арсенала сэра (на тот момент мистера) Ф. Абеля (F. Abel $)^{4}$ о переходе с открытого на закрытый тест определения температуры вспышки. В связи с этим граница для «безопасного» керосина была понижена до $73{ }^{\circ} \mathrm{F}$, поскольку по данным сэра Ф. Абеля температура вспышки $73^{\circ} \mathrm{F}$ в новом приборе соответствует температуре вспышки $100^{\circ} \mathrm{F}$ в аппарате старой конструкции (открытый тигель) [2-4]. Таким образом, с британской позиции никакого «надлома привычек» Парламента Великобритании не было, а его решения в полной мере последовательны и правомерны.

Поскольку в научно-практической деятельности Д.И. Менделеева отсутствует, такая черта, как небрежность, поэтому возникает закономерный вопрос: кто прав? Для решения этой задачи потребуется реконструкция основных событий, связанных с данным вопросом, которые произошли в 60-80-е годы 19-го столетия.

Рассматриваемый период выпадает на начальный этап керосиновой эры, когда керосиновое освещение пришло на смену свечному. Побочным негативным эффектом этого прогрессивного этапа развития человеческого общества, явился рост пожаров и взрывов из-за использования «небезопасного» керосина. Данное обстоятельство побудило многие страны устанавливать лимиты (пределы) для безопасного керосина $\left(\mathrm{T}_{\text {без }}\right)$. Первый шаг в этом направлении был сделан Великобританией, которая являлась основным импортером американского керосина. В сущности, значение равное $100^{\circ} \mathrm{F}$ возникло из уравнения:

$$
\mathrm{T}_{\text {без }}=\mathrm{RT}+\Delta
$$

где RT - средняя комнатная температура комнатная температура в Британии, $\mathrm{RT}=73^{\circ} \mathrm{F} ; \Delta-$ прирост температуры осветительного масла за счет аккумуляции теплоты солнечного света, теплового излучения пламени керосинового прибора, $\Delta \approx 27^{\circ} \mathrm{F}$.

В литературе [5] отмечается, что решение Британского Парламента было принято на основе кон-

\footnotetext{
${ }^{4}$ Рыцарский титул сэра был пожалован мистеру Фредерику Абелю в 1883 году.
}

сультаций доктора Г. Лезэби (H. Letheby) и его экспериментальных данных, что при обычных условиях хранения и эксплуатации керосина его температура не достигает 100 ㄷ․ Однако прямых доказательств этому авторам не удалось обнаружить, но установлено, что в 1864 году доктор Лезэби совместно с другими исследователями предлагал повысить лимит для безопасного керосина до $125^{\circ} \mathrm{F}$ по температуре воспламенения [6]. Необходимо также отметить, что на момент принятия этого закона в Британии уже существовал безопасный предел $130{ }^{\circ} \mathrm{F}$ по температуре воспламенения горючих жидкостей, установленный Медицинской аналитической комиссией (Lancet Analytical Commission) [7]. Однако при принятии Нефтяного закона 1862 года он не был принят во внимание Британским парламентом. Установление легитимного лимита для безопасного керосина в $100^{\circ} \mathrm{F}$ создавало для местных нефтепромышленников неравные условия для конкуренции с американским продуктом на рынке Великобритании. ${ }^{5}$ Однако Британский парламент в большей степени полагался на мнение не местного бизнеса, а Нефтяной ассоциации (Petroleum Association), ${ }^{6}$ которая фактически лоббировала импорт зарубежного керосина на территорию Британской империи.

Следует заметить, что Нефтяной закон 1862 года не был лишен недостатков. Во-первых, официальное определение «петролеума» не давало ответа на вопрос: какая температура (вспышки или воспламенения) заложена для контроля, поэтому в литературе того периода также встречается трактовка данного лимита, как температуры воспламенения [9]. Во-вторых, в нем отсутствовал легитимный метод и прибор для определения безопасного лимита (температуры, при которой тестируемая горючая жидкость выделяет горючие пары). Эти огрехи были устранены в новой редакции Нефтяного закона от 1868 года $[2,4]$. Так появились английский стандартный прибор (English Standard Tester) и нафтометр Метрополии (Metropolitan Oil Tester), которые были зарегистрированы в качестве официальных аппаратов по Нефтяному закону 1868 года (рис. 1) [4, 10]. Не нужно полагать, что создание этих приборов происходило на «голом месте». К этому времени на террито-

\footnotetext{
${ }^{5}$ Для британского керосина $\mathrm{T}_{\text {всп }}$ составляла не менее $120^{\circ} \mathrm{F}$ [8], что требует дополнительных технологических операций по удалению легколетучих компонентов нефти (нафты), а это в свою очередь отражается на конечной стоимости керосина.

${ }^{6}$ Во второй половине 19-го столетия Нефтяная ассоциация также выполняла роль надзорного органа, без её разрешения ни одна зарубежная компания не могла поставлять и/или торговать нефтепродуктами на территории Великобритании.
} 


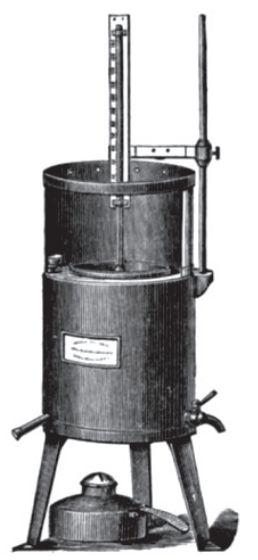

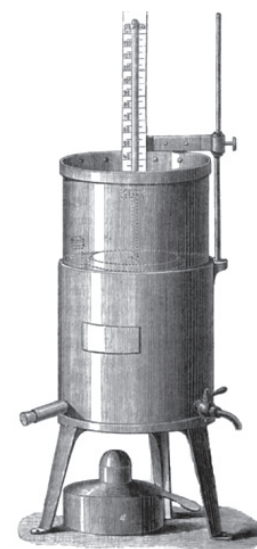

a

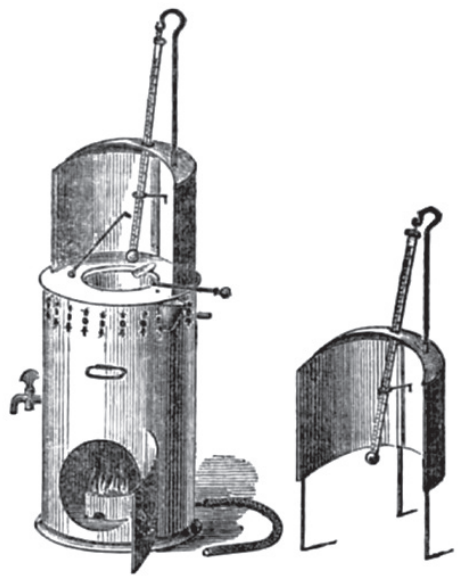

6

Рис. 1. Официальные тестеры по Нефтяному закону 1868 года

$a$-стандартный английский прибор [4]; б-нафтометр Метрополии [10]

рии Британских островов уже применялись грубые (примитивные) методы [4], полузакрытый прибор Антонио Касертелли (Anthony Casartelli) ${ }^{7}$ [11], петролеометр Джона Эттфилда (petroleometer of John Attfield) [12] и другие нафтометры.

В июне 1868 года Ф. Абель предложил Министерству внутренних дел (Home Office) «прибор трех химиков» (Ф. Абеля, Г. Лезэби и Дж. Эттфилда) и метод для определения лимита по Нефтяному закону 1862 года, которые были результатом проведения целой серии экспериментов и опытов данной командой [14].

Первоначально масляный тигель «прибора трех химиков» имел следующие размеры $-3 \times 1,5$ дюйма [14]. Однако на стадии подготовки и рассмотрения новой редакции Нефтяного закона размеры нефтяного тигля без согласования с командой «трех химиков» [15] были изменены [14] и стали $(2 \times 2$ дюйма). Переход от пробирочного к чашечному типу тигля способствует большему рассеиванию паров керосина, вследствие чего значение наблюдаемой температуры вспышки горючей жидкости возрастает [12]. Фактически изменение формы и размеров масляного тигля сводит на нет все усилия команды «трех химиков» по созданию стандартного нафтометра. В связи с этим возникает вопрос - зачем это было сделано, ответ на который дает латинское выражение is fecit cui prodest ${ }^{8}$ из римского права.

В 1867 году Американский конгресс установил предел для безопасного керосина в $110^{\circ} \mathrm{F}[16]$, поэ-

\footnotetext{
7 Данный аппарат более известен как нафтометр Эдварда Парриша (Edward Parrish), который в 19-м столетии применялся в качестве государственного тестера в Голландии [13].

${ }^{8}$ Сделал тот, кому это выгодно.
}

тому представители английского нефтяного бизне$\mathrm{ca}$, связанные с торговлей американским керосином на территории Великобритании, были заинтересованы в принятии нефтяного закона с сохранением лимита для петролеума в $100{ }^{\circ} \mathrm{F}$ и в модифицированной версии «прибора трех химиков». Однако лоббисты не были сильны в тонкостях экспериментального определения лимита для безопасного керосина (петролеума). В США использовался огненный тест по температуре воспламенения в приборе Джона Тальябу (John Tagliabue) (рис. 2) [14], а в Нефтяном законе 1868 года заложен тест по температуре вспышки (flashing test). В дальнейшем Ф. Абелем было показано, что температура вспышки керосина $100{ }^{\circ} \mathrm{F}$ в стандартном английском приборе (рис. 1а) примерно соответствует температуре воспламенения $120^{\circ} \mathrm{F}$ в открытом тигле Джона Тальябу (рис. 2) [5, 14].

Официальные приборы (см. рис. 1) и методика определения температуры вспышки осветительных масел (керосина) по Нефтяному закону 1868 года стали предметом изучения многими исследователями. В результате чего последовали многочисленные предложения по их усовершенствованию, а также предложение новых моделей. Среди них можно отметить тестер компании «Эрнике и Ганнеманн» («Ernecke und Hannemann») [18] и пирометр угольной нефти (coal oil pyrometer) Чарльза Поттера (Charles Potter) [19], которые широко использовались в континентальной Европе и Канаде соответственно, но они не получили официального признания на Британских островах. Принципиальный шаг в этом направлении был сделан в 1871 году химиком-консультантом рабочего совета Метрополии (Metropolitan Board of Works) Т.У. Китес (T.W. Keates), который заключается не только в создании нового полузакрытого прибора на базе стан- 

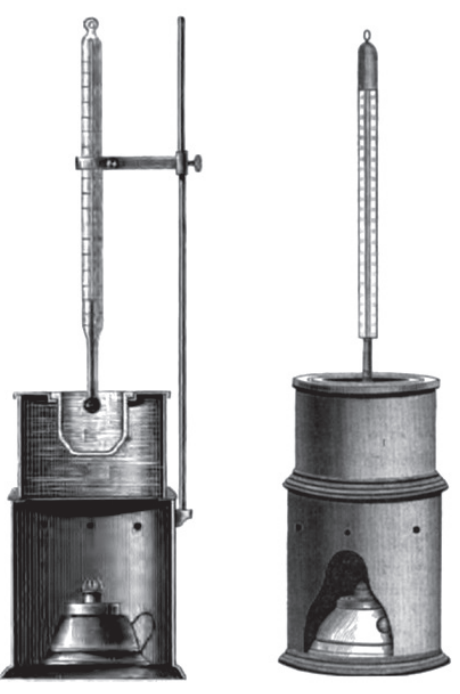

a

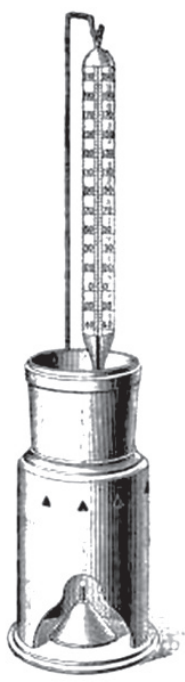

Рис. 2. Нафтометры 60-70-х годов 19 столетия

a- фабричные модели тестера Джона Тальябу [5, 14]; б-тестер Kитеса (б) [5, 14]; в- франиузский полузакрытый тигель [17] дартного английского аппарата по Нефтяному закону 1868 года (рис. 6б), но в его попытке легализовать данный аппарат [5, 14]. Так в проекте Нефтяного закона от 1871 года (Petroleum Bill 1871) предлагалось заменить открытый на закрытый тест, и установить новый лимит для безопасного керосина $-85^{\circ} \mathrm{F}$ по тестеру его конструкции [20]. Данное предложение не было принято Британским парламентом, но идея прибора Китеса воплотилась во французском аппарате (рис. 2в) [17].

Официальная методика определения температуры вспышки 1868 года не была идеальной. В частности, неопределенность понятия маленькое (запальное) пламя, а также отсутствие указаний по скорости нагрева, глубине погружения масляного термометра и зависимость значения температуры вспышки от глубины увеличивали роль человеческого фактора и не обеспечивали хорошую прецизионность метода определения температуры вспышки $[16,18]$. В связи с этим в 1875 году Британское правительство с согласия и одобрения рабочего совета Метрополии и Нефтяной ассоциации обратилось к профессору Ф. Абелю для решения следующих вопросов:

1) является ли метод определения температуры вспышки по Нефтяном закону 1871 приемлемым, и дает ли он удовлетворительные результаты,

2) если нет, то какой метод может быть рекомендован с учетом небольшого экспериментального опыта нефтяных инспекторов и других особ,

\footnotetext{
${ }^{9}$ Конструктивно прибор Китеса относится к полузакрытому типу аппаратов.
}

3) существующий лимит для безопасного керосина $100{ }^{\circ} \mathrm{F}$ (или его эквивалент в новом методе) достаточен или нет.

В 1876 году Ф. Абелем эта задача была выполнена и подготовлен отчет, в котором на 1-й вопрос был дан отрицательный ответ, поэтому им был предложен новый прибор и метод для определения температуры вспышки осветительных масел (рис. 3). Оснований для пересмотра старого лимита он не нашел. Для установления эквивалентного лимита требовались дополнительные исследования, которые в последующем им были проведены с участием Т.У. Китеса из рабочего совета Метрополии, Дж. Колдевуда (J. Calderwood) из Шотландской нефтяной ассоциации (Scottish Mineral Oil Association) и Б. Редвуда из Нефтяной ассоциации. В результате, которых установлено, что средняя разница в показаниях температуры вспышки на приборах старой и новой конструкции составляет $27^{\circ} \mathrm{F}$. В связи с этим новый лимит должен быть равен $73{ }^{\circ} \mathrm{F}[2,14]$.

Закрытый тестер Абеля (рис. 3) состоит из латунного цилиндрического масляного тигля $2 \times 2,2$ дюйма с плотно закрывающейся крышкой, которая оборудована скользящей заслонкой с запальной горелкой и оснащена масляным термометром. Тигель установлен в воздушную ванну диаметром 3 дюйма и 2,5 дюйма глубиной, которая расположена в водяной бане $5,5 \times 53 / 4$ дюйма. Водяная баня снабжена термометром и воронкой для её заполнения. Комбинация двух бань обеспечивает плавный нагрев масляного тигля. Тестер и метод Абеля для определения температуры вспышки были 


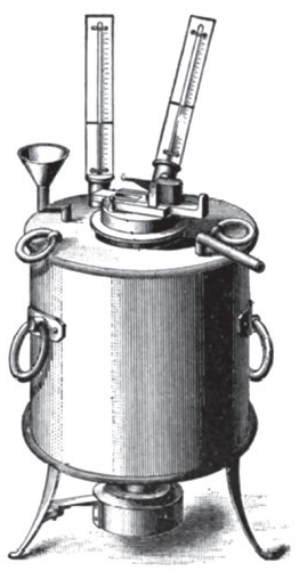

a

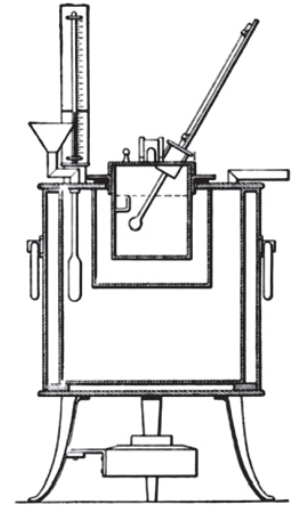

6

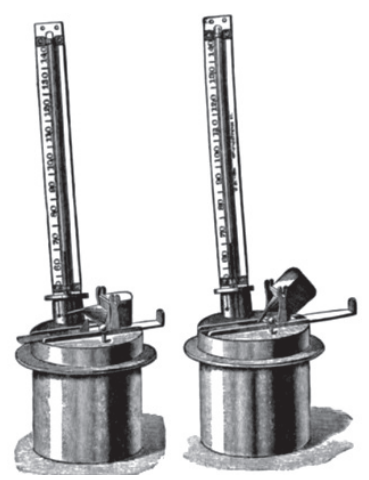

B

Рис. 3. Тестер Абеля [3, 5]

$a$-общий вид; б-разрез; в - тигли с закрытой и открытой заслонкой

легализованы в Нефтяном законе 1879 года [2]. В модифицированном виде они применяются до сих пор [2, 21].

В 1892 и 1896 годах появляются статьи Д.P. Стюарта (D.R. Steuart), в которых он ставит под сомнение не только значение $\left(73^{\circ} \mathrm{F}\right)$ для лимита безопасного керосина, но и способ его установления. Им также отмечается, что на его обращение за разъяснениями по этому поводу была получена только отписка от сэра Ф. Абеля о том, что ему было запрещено общаться на эту тему, а ответа от Б. Редвуда не последовало [22-24]. Публикации Д.Р. Стюарта вызвали доброжелательный отклик в СМИ и был поднят вопрос об увеличении лимита до $100{ }^{\circ} \mathrm{F}$ по методу Абеля [2536]. В 1911 году вышла книга [37], в которой неизвестным автором под псевдонимом «Правдивый исследователь» (“Trusth's” investigator) кратко описана история появления лимита $73{ }^{\circ} \mathrm{F}$ для безопасного керосина и отмечено, что к этому значению сэр Ф. Абель пришел под влиянием заинтересованного лица - сэра Б. Редвуда. ${ }^{10}$ Также отмечено, что к решению задачи по установлению эквивалентного значения керосинового лимита сэром Ф. Абелем не были привлечены его партнеры по созданию «прибора трех химиков», которые обладали высокой компетентностью и были готовы принять участие в данном проекте.

Для ответа на вопрос справедливы ли высказанные замечания в адрес Ф. Абеля и Б. Редвуда проведем критический анализ установленных обстоятельств дела. Наличие двух бань в приборе Абеля (рис. 3б) обеспечивает медленный и равно-

\footnotetext{
${ }^{10}$ Рыцарский титул сэра был пожалован мистеру Б. Редвуду
} в 1905 году. мерный нагрев тигля, что приближает метод Абеля к современной равновесной методике определения температуры вспышки, поэтому неудивительно, что полученные значения этого показателя пожарной опасности в аппарате Абеля меньше, чем в других тестерах.

Нафтометр открытого типа Джона Тальябу (рис. 2a) можно рассматривать как близкий аналог английских приборов открытого типа по Нефтяному закону 1868 и 1871 годов (рис. 1). Отсутствие защитного экрана у тестера Дж. Тальябу, как отмечалось выше, может способствовать незначительному увеличению значения температуры вспышки. Это означает, что приведенная в таблице разница значений между температурами вспышки $(\Delta)$ при замене прибора Дж. Тальябу на открытый аппарат по Нефтяному закону 1868 и 1871 годов будет на несколько градусов меньше. Необходимо отметить, что разница в $20^{\circ} \mathrm{F}$, найденная Ф. Абелем между температурой воспламенения на приборе Дж. Тальябу и температурой вспышки на аппарате по Нефтяному закону 1868 (1871) года [5, 14], практически совпадает со значением $20,4{ }^{\circ} \mathrm{F}$, полученным Чарльзом Чандлером (Charles F. Chandler) при тестировании 100 образцов керосина на нафтометре Дж. Тальябу [38]. Также этот результат согласуется с данными Г.Б. Конволла (Н.B. Cornwall), у которого эта средняя разница составила $17,4^{\circ} \mathrm{F}$ при испытании 9 образцов осветительных масел [39]. Таким образом, использование в нашем сравнительном анализе прибора Дж. Тальябу вместо аппарата по Нефтяному закону 1868 (1871) вполне оправдано.

В таблице приведены результаты сравнительного анализа открытого и закрытого тестов по Дж. Тальябу и Абелю. По данным американско- 
Температура вспышки по методам Дж. Тальябу и Абеля

\begin{tabular}{|c|c|c|c|c|}
\hline \multirow{2}{*}{ Образец } & \multicolumn{2}{|c|}{ Температура вспышки, ${ }^{\circ} \mathbf{F}$} & \multirow{2}{*}{$\Delta,{ }^{\circ} \mathbf{F}$} & \multirow{2}{*}{ Ссылка } \\
\hline & Дж. Тальябу & Абель & & \\
\hline 1 & 110 & 103 & 7 & [40] \\
\hline 2 & 111 & 102 & 9 & [40] \\
\hline 3 & 119 & 102 & 17 & {$[40]$} \\
\hline 4 & 97 & 76 & 21 & {$[40]$} \\
\hline 5 & $\begin{array}{c}72,9(\min ) \\
101,8(\max )\end{array}$ & $\begin{array}{l}60,8(\min ) \\
62,8(\max )\end{array}$ & $\begin{array}{l}12,1(\min ) \\
39,0(\max )\end{array}$ & [41] \\
\hline 6 & $\begin{array}{c}86,9(\min ) \\
119.8(\max )\end{array}$ & $\begin{array}{l}72,0(\min ) \\
74.8(\max )\end{array}$ & $\begin{array}{l}14,9(\min ) \\
45,0(\max )\end{array}$ & [41] \\
\hline 7 & $\begin{array}{c}113,9 \text { (min) } \\
209,8 \text { (max)* }\end{array}$ & $\begin{array}{l}90,3(\min ) \\
92,8(\max )\end{array}$ & $\begin{array}{c}23,6(\min ) \\
-\end{array}$ & [41] \\
\hline
\end{tabular}

* Ошибочное значение в статье [41] связано с опечаткой.

го профессора А. Эллиота (A. Elliott) эта разница лежит в пределах от 7 до $21^{\circ} \mathrm{F}$ (табл.) [40]. Более детальное исследование проведено инженером-технологом В.К. Долининым [41], которым установлены минимальные и максимальные значения температуры вспышки в приборах Дж. Тальябу и Абеля. Из таблицы видно, что $\Delta$ по минимальным значениям температуры вспышки составляет от 12,1 до $23,6{ }^{\circ} \mathrm{F}$. В тоже время разница по максимальным значениям достигает значения порядка $40{ }^{\circ} \mathrm{F}$. Это означает, что для работы на приборе Дж. Тальябу требуется специальная подготовка испытателя. Также В.К. Долининым установлено, что незначительное увеличение высоты пламени горелки приводит к уменьшению температуры вспышки примерно на 2-3 ${ }^{\circ} \mathrm{F}$ в аппарате Абеля [41]. Тем не менее, можно констатировать, что влияние человеческого фактора в методе Абеля значительно меньше, чем в открытом тесте на приборе Дж. Тальябу. Отмечалось, что увеличение времени испытаний на 6-9 минут на приборе Дж. Тальябу приводит к возрастанию значения фиксируемой температуры вспышки на 3-4 F [39].

Из описаний сравнительных тестов [5, 14], проведенных Ф. Абелем с коллегами, следует, что в них использованы разные выборки образцов керосина. Выше отмечалось, что открытый тест на вспышку достаточно чувствителен к условиям проведения испытаний, поэтому использование простого усреднения результатов испытаний просто некорректно для разных выборок образцов керосина. В данном случае необходимо было, чтобы каждая группа исследователей провела испытания одной и той же выборки образцов керосина, однако этого не было сделано.
Следует учесть, что изменение английского лимита для безопасного керосина происходили на заключительном этапе американской нефтяной войны, в которой одерживала победу компания «Стандарт Ойл» (“Standard Oil”) Джона Д. Рокфеллера (John D. Rockefeller). В 1879 году она уже контролировала порядка 90 \% всей американской нефтепереработки [42], поэтому вопросы сбыта нефтепродуктов были для нее очень актуальны. Перед проведением сравнительных тестов Б. Редвуд, как секретарь Нефтяной ассоциации Великобритании, которая отвечала за допуск импортных нефтепродуктов на рынок Великобритании, провел встречу с руководством компании «Стандарт Ойл» [37, 43]. Безусловно, что на этом рандеву поднимался вопрос о поставках американского керосина в Великобританию. Не исключено также, что озвучивалось негативное отношение компании «Стандарт Ойл» к открытому тесту на вспышку (воспламенения) [44]. Если учесть дальнейшее сотрудничество сэра Б. Редвуда по продвижению интересов компании «Стандарт Ойл» в Великобритании [37, 43], то предположение об его заинтересованности в понижении лимита для безопасного керосина на Британских островах становится обоснованным.

На основании экспериментального опыта авторов можно отметить, что несовершенство методики испытаний по Нефтяному закону 1868 (1871) года фактически допускало проведение некоторых манипуляций (изменение скорости нагрева, вариации с пламенем источника зажигания, дополнительный нагрев масляного термометра запальным пламенем), которые влияют на значение наблюдаемой температуры вспышки керосина. К тому же 
на территории Канады при переходе с открытого теста на прибор Абеля в 1880 году вопрос о безопасном лимите керосина решили совершено иначе $-95^{\circ} \mathrm{F}$ по прибору Абеля или $115^{\circ} \mathrm{F}$ в открытом тигле [45].

Из приведенных данных в таблице 111.855(c) «Специальных требований для резервуаров» ("Special Requirements for Tank Vessels") следует, что интервале от 80 до $150{ }^{\circ} \mathrm{F}$ легитимная разница между температурами вспышки в открытом и закрытом тиглях составляет всего лишь $5-10^{\circ} \mathrm{F}[46]$.

Таким образом, на основании вышеизложенного можно сделать следующие выводы:

1. лимит $100{ }^{\circ} \mathrm{F}$ для безопасного керосина, установленный в 1862 году, не обеспечивал в полной мере пожаровзрывобезопасность при его использовании;

2. позиция Нефтяной ассоциации сыграла свою роль в блокировании Британским парламентом предложений по повышению лимита для безопасного керосина;

3. при переходе на новый лимит $73^{\circ} \mathrm{F}$ присутствовала заинтересованность в его установлении;

4. необходимости в прямой фальсификации результатов контрольных испытаний 1000 образцов керосина не было, так как несовершенство методики испытаний по Нефтяному закону 1868 (1871) года, а также организация этих сравнительных тестов позволяла без особых усилий достигнуть желаемого результата для Нефтяной комиссии при Британском парламенте;

5. утверждение Д.И. Менделеева о «надломе привычек» Британского парламента следует признать не в полной мере справедливым.

\section{Литература}

1. Менделеев Д.И. Сочинения. Под ред. В.Г. Хлопина, С.И. Вольфковича, И.В. Гребенщикова и др. Л.-М.: изд-во АН СССР. 1949. Т. 10. С. 492.

2. Алексеев С.Г., Смирнов В.В., Барбин Н.М. История науки и техники. 2017. № 12. С. 60.

3. Алексеев С.Г., Смирнов В.В., Алексеев К.С., Барбин Н.M. Российский химический журнал. 2019. Т. 63 (в печати).

4. Алексеев С.Г., Смирнов В.В., Барбин Н.М. Российский химический журнал. 2018. Т. 62. №3. С. 71-87.

5. Thomson J.H., Redwood B. Handbook on Petroleum. London: Charles Griffin \& Co. 1913. 428 p.

6. The Medical Times and Gazette. 1864. V. 1. P. 245.

7. Gibbons W.S. Kerosene oil: What it is; with causes and prevention of accidents in its use, together with upwards of fifty analyses and experiments with samples sold in Melbourne. Melbourne: F. Bailliere, Publisher \& Importer. $1862.33 \mathrm{p}$.
8. The Journal of Gas Lighting, Water Supply, \& Sanitary Improvement. 1869. V. 18. №438. P. 617.

9. The Chemicals News and Journal of Physical Science. 1862. V. 6. № 148. P. 169.

10. Griffin J.J. Chemical Handicraft: A Classified and Descriptive Catalogue of Chemical Apparatus, Suitable for Performance of Class Experiments, for Every Process of Chemical Research and for Chemical Testing in the Arts. Accompanied by Copious Notes, Explanatory of the Construction and Use of The Apparatus. London: John Joseph Griffin \& Sons. 1877. P. 269-323.

11. Tate A.N. Petroleum and its Products. London: John W. Davies. 1863. P. 86.

12. Attfield J. Pharmaceutical Journal and Transactions. Second Series. 1866. Vol. 8. P. 318.

13. Алексеев С.Г., Смирнов В.В., Барбин Н.М. Российский химический журнал. 2019. Т. 63. № 1. С. 55.

14. Thomson J.H., Redwood B. Handbook on Petroleum. London: Charles Griffin \& Co. 1901. 386 p.

15. Attfield $J$. The Pharmaceutical Journal and Transactions. Third Series. 1871. V. 2. P. 43.

16. Chandler C.F. Report on the Quality of the Kerosene Oil Sold in the Metropolitan District. New York: D. Appleton \& Co. 1870. 23 p.

17. Elliott G.H. Report of a Tour of Inspection of European Light-House Establishments. Washington: Government Printing Office. 1874. $11 \mathrm{p}$.

18. Jahres-Bericht über die Leistungen der chemischen Technologie. 1870. Bd. 16. S. 697.

19. Daily British Colonist. 1875. V. 33. №51 (Feb. 11).

20. The Pharmaceutical Journal and Transactions. Third Series. 1871. V. 2. P. 1002.

21. Алексеев С.Г., Смирнов В.В., Барбин Н.М. Пожаровзрывобезопасность. 2012. Т. 21. № 5. С. 35.

22. Steuart D.R. Journal of the Society of Chemical Industry. 1892. V. 11. №11. P. 885. Doi: 10.1002/ jctb.5000111112.

23. Steuart D.R. The Chemical Trade Journal. 1892. V. 11 № 291. P. 387.

24. Steuart D.R. The Journal of the Society of Chemical Industry. 1896. V. 15. №3. P. 173. Doi: 10.1002/ jctb.5000150301.

25. The Chemical Trade Journal. 1895. V. 17. №448. P. 389.

26. The Chemical Trade Journal. 1896. V. 19. №476. P. 3.

27. The Chemical Trade Journal. 1897. V. 21. №537. P. 148.

28. The Chemical Trade Journal. 1897. V. 21. №514. P. 217.

29. Griffiths G. The Chemical Trade Journal. 1897. V. 21 №546. P. 295.

30. The Chemical Trade Journal. 1897. V. 21. №551. P. 374.

31. The Chemical Trade Journal. 1898. V. 22. № 557. P. 52.

32. Remmett W.A., Wright B.J.W., Page W.H. The Chemical Trade Journal. 1899. V. 24. №614. P. 140.

33. The Chemical Trade Journal. 1899. V. 24. №617. P. 185.

34. The Chemical Trade Journal. 1899. V. 24. №617. P. 189. 
35. The Chemical Trade Journal. 1899. V. 24. №621. P. 249.

36. The Engineer. 1898. V. 86. P. 13.

37. "Truth's" investigator. The Great Oil Octopus. London: T. Fisher Unwin. 1911. P. 207.

38. Chandler C.F. First Annual Report of the Board of Health of the Health Department of the City of New York. April 11, 1870, to April 10, 1871. New York: The New York Printing Co. 1871. P. 512.

39. Cornwall H.B. The American Chemist. 1876. V. 6. № 12. P. 458.

40. Elliott A.H. Methods and apparatus for testing inflammable oils: Report of State Board of Health of New York No 45. Albany: Weed, Parsons and Co., Printers, 1882. $44 \mathrm{p}$.
41. Долинин В.К. Горный журналъ. 1887. Т. 1 (март). C. 442.

42. Yergin D. The Prize. The Epic Quest for Oil, Money, and Power. New York: Simon \& Schuster. 1991. P. 35 .

43. Sorkhabi R. Geological Society Special Publication No 465. History of the European Oil and Gas Industry. London: The Geological Society, 2018. P. 423. Doi:10.1144/sp465.22.

44. Beckwith D.H. The Sanitarian. 1887. V. 18. №208. P. 247.

45. Treaties between her Majesty, the Queen, and Foreign Powers. Ottawa: Brown Chamberlin. 1881. P. 114.

46. Federal Register. 1970. V. 35. №252. P. 19952. 